\title{
PEMBINAAN ITEM DALAM BIDANG PERKAITAN BAGI MATA PELAJARAN MATEMATIK TINGKATAN EMPAT BERDASARKAN MODEL TAKSONOMI PEMPROSESAN MAKLUMAT
}

\author{
${ }^{1}$ Teng Kai Wen, ${ }^{2}$ Nor'ain Mohd Tajudin, ${ }^{3}$ Rohaidah Masri \\ ${ }^{1}$ SMK Tunku Ampuan Najihah, 70200 Seremban, Negeri Sembilan \\ ${ }^{2,3}$ Jabatan Matematik, Fakulti Sains dan Matematik, \\ Universiti Pendidikan Sultan Idris, 35900 Tanjong Malim, Perak
}

Received : 18 April 2017; Accepted : 9 October 2017; Published : 15 December 2017

\begin{abstract}
Abstrak
Kajian ini bertujuan membina lima item dalam bidang Perkaitan bagi mata pelajaran Matematik yang dapat memenuhi lima tahap hierarki Model Taksonomi Pemprosesan Maklumat (TPM). Pembinaan lima item telah disusuli dengan proses kesahan oleh dua orang pakar serta penentuan kebolehpercayaan item. Kesahan pakar dinilai daripada nilai indeks persetujuan Cohen Kappa dan penentuan kebolehpercayaan menggunakan nilai indeks diskriminasi dan kesukaran. Dapatan kajian menunjukkan lima item bidang Perkaitan mengikut tahap hieraki TPM telah berjaya dibina dengan setiap item direka bentuk mengikut ciri-ciri TPM, iaitu mencungkil maklumat dari sumber luar, memori kerja, memori jangka pendek dan memori jangka panjang. Pengeluar maklumat primer dan sekunder pula merupakan sistem yang diaktifkan oleh murid semasa menyelesaikan masalah untuk membezakan tahap pemikiran murid serta menggambarkan proses kognitif murid. Kesimpulannya, lima item Perkaitan memenuhi lima tahap hierarki TPM serta dapat digunakan untuk mempamerkan proses kognitif pelbagai tahap pencapaian murid. Implikasinya, pembinaan item dalam soalan penyelesaian masalah matematik perlu menitikberatkan tahap dan ciri-ciri hieraki TPM supaya pentaksiran dalam proses pengjaran dan pembelajaran lebih efisien.
\end{abstract}

\section{Kata kunci Model Taksonomi Pemprosesan Maklumat, Penyelesaian Masalah matematik, Proses Kognitif.}

\begin{abstract}
This study aims to construct five items of Relationship area for form four Mathematics subject to congregate the five-level hierarchical of Information Processing Taxonomy (IPT) Model. The constructions of five items have been validated by two experts followed by a process of item reliability determination. The experts' validity was assessed using the Cohen's Kappa agreement index value and the reliability was determined through the use of the discrimination and difficulty indices. The findings showed that this study has successfully constructed five items of Relationship area and each item was designed according to the IPT characteristis namely elicit information from the external input, working memory, short term memory and long term
\end{abstract}


memory. The primer and secondary information producer were systems that have been activated by the students while solving problems to differentiate students' level of thinking as well as describing student's cognitive processes. In conclusion, five items of Relationship area congregated the five hierarchy of IPT as well as can be used to exhibit the cognitive processes of various students' achievement level. The implication of this study is mathematical problem solving question constructions need to emphasize on the IPT hierarchy level and its characteristics, so that the assessment in the teaching and learning processes will be more efficient.

\section{Keywords Information Processing Taxonomy Model, Mathematical} Problem Solving, Cognitive Processes.

\section{PENGENALAN}

Pendidikan merupakan pencetus kreativiti dan penjana inovasi yang melengkapkan generasi muda dengan pelbagai kemahiran untuk bersaing dalam pasaran kerja, serta menjadi pengupaya dalam perkembangan ekonomi Malaysia. Bagi memaksimumkan peranannya membentuk dan melahirkan generasi berilmu, kreatif dan inovatif, sistem pendidikan Malaysia sedang mengalami proses perubahan pesat untuk meningkatkan kualiti sistem pendidikan, sebagaimana ditetapkan oleh Falsafah Pendidikan Negara. Ini selaras dengan salah satu teras yang digariskan dalam Wawasan 2020 iaitu meningkatkan keupayaan pengetahuan dan inovasi negara serta memupuk minda kelas pertama.

Bidang penyelesaian masalah merupakan satu bidang yang amat penting dan selalu diberi prihatin dalam kurikulum matematik (Lester, 2013; Schoenfeld, 2013; Nor'ain \& Chinnappan, 2016). Sejak merdeka sehingga sekarang, kurikulum matematik telah mengalami banyak perubahan. Ini terutamanya reformasi yang berlaku dalam kurikulum pendidikan sehingga menukarkan Kurikulum Baru Sekolah Menengah kepada Kurikulum Bersepadu Sekolah Menengah (KBSM) pada tahun 1989. Penyelesaian masalah dalam kurikulum matematik yang berlandaskan penyelesaian masalah Model Polya turut diberi penekanan selari dengan KBSM untuk meningkatkan kualiti pengajaran dan pembelajaran di bilik darjah (Selvamarry, 2013).

Sejajar dengan itu, kemahiran penyelesaian masalah telah diintegrasikan ke dalam kurikulum matematik oleh Kementerian Pelajaran Malaysia (2004). Ini adalah bertujuan untuk membentuk individu yang berpemikiran matematik dan berketrampilan mengaplikasikan pengetahuan matematik dengan berkesan dan bertanggungjawab dalam penyelesaian masalah serta membuat keputusan. Dengan itu, murid perlu dididik dari peringkat awal dengan kemahiran menyelesaikan masalah supaya berupaya untuk menangani cabaran dalam kehidupan seharian kelak (Pusat Perkembangan Kurikulum, 2012).

\section{KAJIAN LITERATUR}

Matematik merupakan satu disiplin ilmu yang sangat penting dalam kehidupan seharian manusia (Nik Azis \& Noraini, 2008). Menurut Wiersman (2000), untuk menyelesaikan suatu masalah, seseorang itu perlu mempunyai daya imaginasi dan kreativiti yang kuat. Mereka hendaklah membuat refleksi terhadap pemikiran dan strategi yang digunakan. Di samping itu, pelbagai kemahiran dan strategi penyelesaian 
masalah perlu dikerjakan oleh murid dengan menggunakan pengetahuan matematik, membina pemahaman baru dan kemahiran berfikir mereka (Kilpatrick \& Swafford, 2002). Kajian ini mendapati penyelesaian masalah matematik menimbulkan banyak kesukaran dan kesilapan dalam kalangan murid sehingga mereka gagal melaksanakan penyelesaian dengan betul dan sempurna.

Analisis kajian PISA 2012 menunjukkan kedudukan Malaysia terletak di tangga 52 iaitu dalam kelompok sepertiga terbawah dalam kalangan 64 negara peserta. $50.5 \%$ peserta Malaysia gagal mencapai tahap kemahiran minimum atau tanda aras minimum dalam Matematik (Kementerian Pendidikan Malaysia, 2013). Manakala hanya $0.9 \%$ peserta mencapai tahap kemahiran tinggi. Definisi PISA 2009 tentang tahap kemahiran minimum bermaksud murid tidak dapat menggunakan algoritma asas, formula atau prosedur. Secara khususnya, murid di Malaysia tiada kebolehan melakukan penaakulan terus dan membuat interpretasi literal bagi sesuatu keputusan. Mereka hanya mampu menjawab soalan yang jelas melibatkan konteks biasa (Kementerian Pendidikan Malaysia, 2013). Jika dibanding dengan prestasi negara serantau seperti Singapura (562), Korea (561), Jepun (552) dan Hong Kong (540), prestasi Malaysia (422) adalah jauh lebih ketinggalan. Mengikut pentakrifan mata dalam PISA (2009), perbezaan 38 mata bersamaan dengan pembelajaran satu tahun persekolahan. Ini bermakna, murid berusia 15 tahun di Malaysia seolah-olah ketinggalan hampir tiga tahun persekolahan berbanding dengan murid yang seusia di negara pesaing Malaysia dalam ekonomi pengetahuan masa kini.

Seterusnya, keputusan kajian TIMSS 2011 (Mullis, Martin, Minnich, Stanco, Arora, Centurino \& Castle, 2012) juga menunjukkan penurunan prestasi dan kejatuhan kedudukan matematik yang mendadak di peringkat antarabangsa. Pentaksiran TIMSS adalah berasaskan kurikulum sekolah bagi mata pelajaran Matematik dan Sains di seluruh dunia. Skop pentaksirannya merangkumi dua aspek utama iaitu pengetahuan kandungan seperti nombor, algebra, geometri dan kemahiran kognitif seperti proses pemikiran penguasaan pengetahuan, aplikasi, mengorganisasi, membuat kesimpulan daripada maklumat, membuat generalisasi dan menyelesaikan masalah bukan rutin dan penaakulan. Prestasi matematik murid Malaysia mula menurun di bawah purata antarabangsa dalam TIMSS 2007. Laporan TIMSS 2011 mendedahkan kejatuhan kedudukan Malaysia dalam pembelajaran Matematik di Malaysia iaitu 20 (2007) dan 26 (2011). Begitu juga dengan kejatuhan skor purata bagi subjek matematik iaitu 519 (1999), 508 (2003), 474 (2007) dan 440 (2011) (Mullis et al., 2012).

Dalam laporan TIMSS 2011, terdapat 43\% daripada murid Malaysia menjawab soalan yang menguji pengetahuan dengan betul. Ini dapat ditaksirkan bahawa kebanyakan murid Malaysia masih tidak mampu menjawab dengan baik bagi soalan beraras rendah mahupun beraras tinggi (Zabani, 2012). Menurut definisi TIMSS, tahap pencapaian minimum bermaksud murid hanya mampu menggunakan pengetahuan asas matematik dalam situasi yang mudah sahaja (Mullis et al., 2004). Mereka hanya boleh menyelesaikan masalah berayat yang melibatkan hanya satu langkah penyelesaian serta menterjemahkan dan membaca graf dan jadual. Murid kita hanya mampu memahami hubungan algebra yang mudah sahaja tetapi tidak dapat mengaplikasi pengetahuan pada amnya. Ini menggambarkan bahawa murid kita masih lemah dalam bidang Perkaitan terutamanya topik algebra.

TIMSS, secara khususnya mentaksir penguasaan murid dalam ketiga-tiga jenis kemahiran kognitif yang berlainan, iaitu mengingat pengetahuan, mengaplikasi pengetahuan dan kebolehan menaakul dalam penyelesaian masalah (Mullis et al., 2004). Malangnya, murid Malaysia tidak dapat melaksanakan dengan baik dalam 
ketiga-tiga dimensi ini (Kementerian Pendidikan Malaysia, 2013). Untuk mencapai prestasi matematik yang setaraf dunia, sistem pendidikan Malaysia perlu memberi tumpuan kepada soalan yang menguji kemahiran berfikir yang beraras tinggi seperti aplikasi dan penaakulan. Ini adalah syarat mencapai tahap lanjutan dalam PISA, iaitu murid dapat membuat interpretasi maklumat yang lebih kompleks dan mengolah sebilangan langkah pemprosesan. Mereka boleh menunjukkan keupayaan berfikir dengan mengenal pasti strategi penyelesaian yang sesuai dan mempamerkan proses kognitif beraras tinggi bagi menerangkan atau menyampaikan keputusan. Berdasarkan syarat di atas, penyelidikan dalam bidang kognisi harus lebih tertumpu kepada proses kognitif murid terutamanya sistem pengeluar maklumat yang digunakan untuk mencungkil maklumat di memori jangka panjang dan memori jangka pendek murid sepertimana yang dikaji oleh Fong (1994).

Analisis laporan TIMSS 2007 hingga tahun 2011 dan PISA 2012 tersebut selari dengan kajian Tengku Zawawi (2005) yang menunjukkan bahawa murid Malaysia hanya menghafal petua dan rumus untuk melakukan proses pengiraan. Didapati juga, ramai guru melakukan ulangan sesi pengajaran kepada murid yang masih tidak faham pelajarannya. Mengikut kajian Tengku Zawawi (2005), kebanyakan guru menganggap bahawa murid yang memahami pelajaran dapat menyelesaikan masalah dan murid yang tidak memahami pelajaran tidak dapat menyelesaikan masalah. Oleh itu, latih tubi dijadikan satu kaedah untuk memudahkan murid mengingat rangka atau format dalam menyelesaikan masalah. Kaedah ini menyebabkan mereka senang lupa langkah yang dipelajarinya. Mereka juga gagal menyelesaikan masalah yang sama pada waktu yang lain. Ini mungkin kerana cara atau strategi menyelesaikan masalah tidak dapat kekal dalam ingatan mereka sehingga mengalami gangguan pemprosesan maklumat murid semasa menyelesaikan masalah.

Pendapat Tengku Zawawi (2005) ini sepadan dengan pendapat Lutz dan Huitt (2003) bahawa pengulangan latih tubi sebenarnya didapati tidak cukup untuk menghasilkan kesan yang berkekalan. Selain itu, Salmah (2003) menegaskan murid selalu menggunakan pemahaman mereka sendiri untuk menjawab soalan penyelesaian masalah. Mereka sukar untuk mengenal pasti strategi penyelesaian masalah yang sesuai. Ini menyebabkan mereka tidak dapat menulis jawapan dengan tersusun sehingga tidak dapat menjawab soalan dengan betul. Driscoll (2005) menyatakan bahawa pembelajaran seseorang sentiasa berubah mengikut tahap prestasi atau potensi diri sebagai hasil dari proses pengalaman belajar dan proses interaksi dengan dunia. Oleh itu, seseorang perlu ada perwakilan rangsangan yang tepat sebelum menyimpan maklumat dalam minda. Maklumat yang masuk dipadan dengan rangsangannya yang sesuai akan menghasilkan ingatan dengan sempurna.

Analisis dapatan kajian di atas hanya dapat menerangkan kegagalan murid menjawab soalan penyelesaikan masalah tanpa melibatkan kajian tentang proses kognitif murid secara mendalam. Persoalannaya bagaimanakah sebenarnya manusia belajar, memperoleh maklumat baru dan mengekalkan maklumat seterusnya menggunakan kefahaman dalam menyelesaikan masalah? Justeru, kajian tentang bagaimana proses kognitif murid semasa menyelesaikan masalah matematik terutama maklumat yang dicungkil dari penyelesaian masalah, maklumat dari memori kerja, memori jangka pendek dan jangka panjang semasa murid semasa menyelesaikan masalah amat relevan masa kini.

Kajian Siti Hadijah (2010) mendapati bahawa murid lemah menjawab soalansoalan yang memerlukan daya ingatan yang tinggi sebelum dapat menterjemahkan sesuatu konsep atau teori yang dikemukakan dalam sesuatu soalan itu. Murid 
juga lemah menjawab soalan berbentuk pengetahuan, membuat kiraan dan tidak mempunyai keupayaan melihat apa yang tersirat di dalam situasi. Ini terutamanya algebra dalam bidang Perkaitan. Murid perlu membuat perwakilan yang sesuai dengan pemboleh ubah. Soalan yang berbentuk abstrak dan sukar dibayangkan dalam kehidupan seharian. Kebanyakan mereka tidak dapat menjawab soalan dengan lengkap dan mendapat markah yang rendah.

Walaupun kurikulum matematik di Malaysia menggunakan model Polya sebagai strategi untuk menyelesaikan soalan berbentuk penyelesaian masalah (Kementerian Pendidikan Malaysia, 2015), namun masih timbul masalah semasa murid menyelesaikan masalah matematik. Ini kerana model Polya merupakan panduan mencari penyelesaian. Model ini tidak dapat menjawab kenapa murid gagal menyelesaikan masalah matematik secara mendalam. Kajian Kaur (2008) pula menjelaskan bahawa murid yang gagal menyelesaikan masalah disebabkan oleh: a) kurang memahami masalah yang diberi; b) kurang pengetahuan merancang strategi penyelesaian; c) tidak dapat menterjermahkan masalah ke dalam bentuk matematik; d) salah mentaksir maklumat yang diberi; d) pengetahuan matematik yang kurang dan e) kesilapan kiraan.

Selain daripada masalah yang tersebut di atas, bidang pentaksiran juga boleh menimbulkan masalah kepada corak pengajaran guru sekali gus pembelajaran murid. Pentaksiran bukan saja bertujuan untuk menentukan kebolehan murid dalam pembelajaran tetapi juga perlu mengenal pasti proses kognitif murid secara berperingkat-peringkat. National Council of Teachers of Mathematics (NCTM) (2014) menegaskan bahawa pemikiran peringkat tinggi harus dijadikan satu keperluan dalam pengajaran dan pembelajaran matematik. Dengan itu, pengajaran dan pembelajaran matematik tidak seharusnya dihadkan atau disekat dengan soalansoalan yang beroreintasi peperiksaan awam atau soalan dalam buku teks. Hasil dapatan kajian Fong (1997) mendapati sesetengah murid cenderung untuk beroperasi pada tahap pemikiran yang lebih tinggi untuk menyelesaikan beberapa langkah yang boleh dikelaskan pada tahap yang lebih rendah operasinya. Justeru, murid mungkin berupaya mengaktifkan minda untuk mengeluarkan maklumat dalam memori jangka panjang oleh sistem pengeluar maklumat mereka dan boleh menyelesaikan masalah yang tidak rutin.

Banyak kajian telah dibuat tentang strategi metakognitif terhadap pembelajaran matematik seperti kajian Zatur Junaida (2004), Roslina (2007) dan Zarimah (2010) tetapi tidak banyak kajian ditumpukan tentang pemprosesan maklumat secara mendalam dalam penyelesaian masalah matematik. Selain itu, kajian Faridah Hanim (2003) menjelaskan kebanyakan kajian yang dijalankan mengkaji pemboleh ubah yang dikaitkan dengan murid seperti pencapaian akademik, konsep kendiri serta sikap dan sebagainya. Setakat ini, kebanyakan penyelidikan tempatan masih memberi fokus kepada kajian yang mengutamakan pembinaan masalah matematik berdasarkan taksonomi Bloom (1956) dan semakan semula Krathwohl (2002) seperti kajian Salmah (2003), Faridah dan Effandi (2012). Ini kerana dalam bidang pentaksiran pendidikan Malaysia, taksonomi tersebut digunakan bertujuan untuk melihat tahap pencapaian murid berdasarkan dimensi mengingat, memahami, menerapkan, menganalisis, menilai dan mencipta (Bloom, 1956; Krathwohl, 2002). Selain itu, taksonomi tersebut juga dijadikan garis panduan utama dalam bidang pendidikan di Malaysia terutamanya dalam penggubalan soalan peperiksaan di sekolah. Akan tetapi, taksonomi tersebut sebenarnya tidak dapat menerangkan proses kognitif murid secara lebih teliti. Oleh itu, Fong (1997) menegaskan kajian tentang pemprosesan 
maklumat murid dalam penyelesaian masalah berdasarkan TPM perlu dilanjutkan sebagai pelengkap sistem pendidikan.

Selain itu, buku teks serta soalan yang digubal oleh para pendidik di sekolah adalah berdasarkan Taksonomi Bloom (Krathwohl, 2002). Taksonomi ini bertujuan untuk menilai tahap pencapaian murid mengikut dimensi mengingat, memahami, menerapkan, menganalisis, menilai dan mencipta. Dengan itu, penyelesaian masalah murid tidak dapat diterangkan melalui proses kognitif secara mendalam. Di samping itu, dalam bidang pentaksiran didapati soalan penilaian UPSR, PT3 dan SPM yang dibina juga berpandu kepada Taksonomi Bloom (Krathwohl (2002). Oleh sebab soalan penyelesaian masalah matematik yang dibina bukan berasaskan model TPM maka sukar untuk para pendidik menilai penyelesaian masalah murid mengikut tahap hierarki yang dicapai.

Dalam kajian ini, bidang Perkaitan yang dipilih meliputi ungkapan algebra, persamaan linear serta nisbah, kadar dan kadaran seperti mana dalam sukatan pelajaran Tingkatan 2 dan 3 (Kementerian Pelajaran Malaysia, 2004). Kajian Egodowatte (2011) menunjukkan murid melakukan kesalahan dan miskonsepsi yang berkaitan dengan konsep pemboleh ubah, ungkapan algebra, persamaan algebra dan soalan berbentuk pernyataan. Johanning (2004) pula berpendapat bahawa guru yang terlalu menekan prosedur dalam membuat pengiraan dan membuat manipulasi bagi simbol-simbol algebra tidak membantu daya pemikiran murid dan meningkatkan pengetahuan murid dalam proses pembelajaran dalam bidang Perkaitan.

Selain itu, murid didapati sukar untuk memindahkan masalah berayat kepada bentuk yang mudah (Salmah, 2003). Kesannya dapat dilihat dalam laporan TIMSS 2011 iaitu murid kita hanya mampu memahami hubungan algebra yang mudah tetapi tidak dapat mengaplikasi pengetahuan pada amnya (Zabani, 2012). Dengan itu, kajian mengenai penyelesaian masalah matematik murid khusus dalam bidang Perkaitan perlu dijalankan. Justeru, perhatian serius dapat diberi terhadap isu yang timbul supaya setiap murid dapat dikesan kelemahan dan kekurangan semasa menyelesaikan masalah matematik serta langkah-langkah proaktif tentang strategi pengajaran penyelesaian masalah matematik dapat dijalankan oleh para pendidik.

Mengambil kira keputusan PISA 2012, TIMSS 2011 dan kajian yang dihuraikan di atas, didapati proses kognitif murid semasa menyelesaikan masalah harus diambil berat untuk menentukan pengetahuan dan kemahiran matematik yang dikuasai oleh murid dalam bidang Perkaitan. Maka, satu kajian mendalam perlu dijalankan dalam bidang penyelesaian masalah matematik, khususnya pembinaan item berdasarkan TPM agar item ini boleh memberikan penjelasan yang lebih tepat tentang persoalan mengapa murid tidak dapat menyelesaikan masalah matematik serta memberi panduan kepada guru matematik dalam membina item pentaksiran.

\section{KERANGKA KONSEPTUAL KAJIAN}

Menurut Fong (1994), Model Taksonomi Pemprosesan Maklumat (TPM) dapat menghuraikan proses kognitif murid dengan lebih terperinci semasa menyelesaikan masalah. Proses kognitif murid boleh dibahagi mengikut fasa-fasa tertentu iaitu sumber luar (SL), memori kerja (MK) dan memori jangka panjang (MP). Maklumat-maklumat yang dicungkil dalam minda murid dapat dikesan melalui sistem pengeluar maklumat primer (P1) dan sekunder (P2) murid. Penyelesaian masalah matematik memerlukan penaakulan, penguasaan pengetahuan konsep serta prosedur dan kemahiran strategi murid. Jadi proses-proses kognitif yang dialami oleh murid semasa menyelesaikan 
masalah matematik haruslah dihuraikan dengan lebih sistematik dan mendalam.

Bagi menghuraikan proses kognitif penyelesaian masalah matematik, kajian ini menggunakan taksonomi yang diperkenalkan oleh Fong (1994) untuk membina lima item bidang Perkaitan mengikut tahap yang berbeza hierarki berdasarkan ciri-ciri pemprosesan maklumat. Model ini juga digunakan untuk menilai keupayaan murid semasa menyelesaikan masalah matematik. Secara ringkas, kerangka kajian bagi menjelaskan pembinaan lima item boleh dilihat dalam Rajah 1.

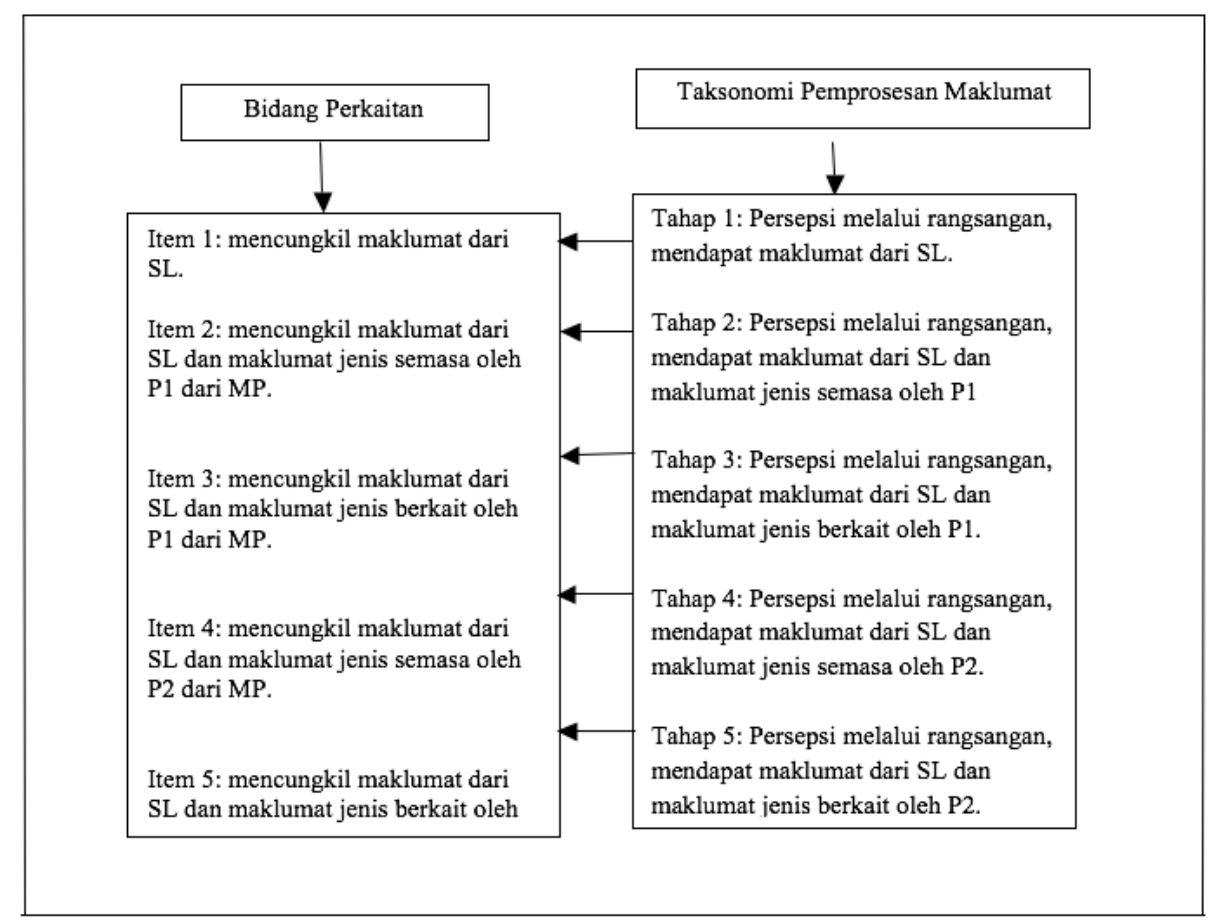

Rajah 1 Kerangka Konseptual Pembinaan Item Bidang Perkaitan (Sumber: Fong (1994)

\section{OBJEKTIF KAJIAN}

Kajian ini bertujuan membina lima item bidang Perkaitan dalam mata pelajaran Matematik tingkatan empat yang memenuhi lima tahap hierarki TPM yang dipelopori oleh Fong (1944) .

\section{METODOLOGI}

Dua peringkat pembinaan item digunakan untuk membina item bidang Perkaitan dalam mata pelajaran Matematik tingkatan empat yang memenuhi lima tahap hierarki TPM iaitu peringkat pertama ialah pengesahan item menggunakan pekali Kappa (Landis \& Kosh, 1977) dan peringkat kedua ialah penentuan kebolehpercayan item yang menggunakan indeks kesukaran dan indeks diskriminasi (Macintosh \& Morrisson, 1969). 
Untuk pengesahan item, item disemak dan dinilai oleh panel penilai yang terdiri daripada dua orang guru cemerlang (GC) matematik dan berkhidmat lebih daripada 10 tahun di sekolah menengah kebangsaan. Mereka menyemak kesesuaian konten, kandungan sukatan pelajaran, tahap kesukaran serta bahasa yang digunakan. Selain itu, kajian rintis juga dijalankan untuk meningkatkan kesahan dan kebolehpercayaan item. Selepas pemilihan item bidang Perkaitan, perbincangan dan komen daripada dua orang GC tersebut tentang kesesuaian soalan yang dipilih dilaksanakan. Kesahan dibuat berdasarkan konten, bahasa, strategi dan kesesuaian tahap hierarki.

Seterusnya, untuk menentukan kebolehpercayaan item, kajian rintis untuk menguji kebolehpercayaan item dilaksanakan. Satu kelas iaitu seramai 20 orang murid telah mengambil ujian rintis. Data yang dikumpulkan diukur tahap kebolehpercayaannya dengan menggunakan Indeks Kesukaran (IK) dan Indeks Diskriminasi (ID) (Macintosh \& Morrisson, 1969). IK mentafsir item seperti yang berikut iaitu: IK $<0.29$ terlalu sukar; $0.3 \leq \mathrm{IK} \leq 0.69$ sederhana; dan IK $>0.7$ terlalu mudah Nilai IK dikira menggunakan formula seperti yang berikut:

Indeks Kesukaran, $\mathrm{IK}=\left(\mathrm{C}_{\mathrm{H}}+\mathrm{C}_{\mathrm{L}}\right) / \mathrm{T}_{(\mathrm{H}+\mathrm{L})}$

$\mathrm{C}_{\mathrm{H}} \quad=$ Jumlah bilangan calon kumpulan skor tinggi yang menjawab soalan dengan betul.

$\mathrm{C}_{\mathrm{L}} \quad=$ Jumlah bilangan calon kumpulan skor rendah yang menjawab soalan dengan betul.

$\mathrm{T}_{(\mathrm{H}+\mathrm{L})}=$ Jumlah bilangan calon yang menjawab soalan.

Selain itu, ID juga digunakan untuk meningkatkan kebolehpercayaan item yang digunakan. ID merupakan kuasa membezakan murid antara kumpulan skor tinggi dan kumpulan skor rendah. Oleh itu, nilai ID boleh digunakan untuk menentukan sama ada sesuatu item tertentu adalah sesuai dan boleh digunakan untuk ujian. Tafsiran item berdasarkan interpretasi berikut: ID $\geq 0.40$ menunjukkan diskriminasi positif tinggi iaitu item sangat sesuai dan boleh diterima; $0.20<$ ID $\leq$ 0.39 menunjukkan diskriminasi positif sederhana iaitu item perlu diubah suai; 0.10 $\leq$ ID $\leq 0.19$ menunjukkan diskriminasi positif rendah iaitu item perlu dibina semula; dan ID $<0$ menunjukkan diskriminasi negatif iaitu item perlu disingkirkan. Nilai ID dikira menggunakan formula seperti yang berikut:

Indeks Diskriminasi, $\mathrm{ID}=\left(\mathrm{C}_{\mathrm{H}}-\mathrm{C}_{\mathrm{L}}\right) / 1 / 2 \mathrm{~T}$

$\mathrm{C}_{\mathrm{H}}=$ Jumlah bilangan calon kumpulan skor tinggi yang menjawab soalan dengan betul.

$\mathrm{C}_{\mathrm{L}}=$ Jumlah bilangan calon kumpulan skor rendah yang menjawab soalan dengan betul.

$\mathrm{T}=$ Jumlah bilangan calon yang menjawab soalan. 


\section{DAPATAN KAJIAN}

\section{Kesahan Item}

Hasil pengesahan oleh dua orang panel penilai GC dipaparkan dapatannya dalam bentuk analisis pekali Kappa dapat dilihat pada Jadual 1.

Jadual 1 Pekali Kappa Daripada Persetujuan Guru Cemerlang

\begin{tabular}{ccc}
\hline Soalan & GC 1 & GC 2 \\
\hline Tahap Hierarki 1 & 1.0 & 1.0 \\
Tahap Hierarki 2 & 1.0 & 1.0 \\
Tahap Hierarki 3 & 1.0 & 1.0 \\
Tahap Hierarki 4 & 0.5 & 0.5 \\
Tahap Hierarki 5 & 0.5 & 0.5 \\
\hline Tahap Hierarki & 0.8 & 0.8 \\
1, 2, 3, 4 dan 5 & & \\
\hline
\end{tabular}

Mengikut Jadual 1 di atas, disimpulkan bahawa pekali Kappa (Landis dan Kosh, 1977) bagi soalan pelbagai tahap ialah 0.8. Secara terperincinya, soalan tahap hierarki 1, 2 dan 3 dapat diterima dengan pekali kappa 1.0 masing-masing oleh keduadua orang GC. Manakala item 4 dan 5 hanya mencapai pekali kappa sebanyak 0.5 masing-masing. Dengan itu, item 4 dan 5 ini telah diubah dan diperbaiki. Kesahan kali kedua dijalankan dan pekali Kappa item 4 dan 5 ialah 1.0. Oleh itu, item yang dibina mempunyai kesahan yang tinggi.

\section{Kebolehpercayaan Item}

Kajian rintis dijalankan kepada 20 orang murid Tingkatan 4 di sebuah sekolah menengah. Berikut merupakan nilai indeks kesukaran (IK) dan indeks diskriminasi (ID) (Macintosh \& Morrisson, 1969) item mengikut tahap hierarki model TPM (Fong, 1994).

Jadual 2 Nilai Indeks Kesukaran dan Indeks Diskriminasi Item Mengikut Tahap Hierarki

\begin{tabular}{lccccc}
\hline & ITEM 1 & ITEM 2 & ITEM 3 & ITEM 4 & ITEM 5 \\
\hline Indeks kesukaran & 0.80 & 0.85 & 0.55 & 0.25 & 0.2 \\
Indeks diskriminasi & 0.40 & 0.30 & 0.90 & 0.5 & 0.4 \\
\hline
\end{tabular}

Berdasarkan nilai pengiraan IK dalam Jadual 2, item 1 (0.8) dapat memberi tafsiran bahawa item tersebut dikategorikan sebagai soalan yang terlalu mudah. Nilai tafsiran ID juga menunjukkan item 1 sangat sesuai dan boleh diterima dalam kajian ini. Manakala tafsiran IK bagi item 2 telah menunjukkan item ini lebih senang daripada item 1, iaitu 0.85. Selain itu, nilai ID iaitu 0.3 menunjukkan soalan ini tidak dapat membezakan antara kumpulan skor tinggi dan kumpulan skor rendah. Oleh itu, item 2 perlu diubah suai untuk meningkatkan kebolehpercayaan kajian. Item 2 ini kemudian diuji dan dianalisis sekali lagi oleh 20 orang murid yang sama. Dapatan analisis telah menunjukkan bahawa item 2 mencapai nilai IK sebanyak 0.62 dan ID sebanyak 0.7. Ini menunjukkan item yang diubah suai mencapai tahap kesukaran 
sederhana dan diskriminasi positif yang tinggi. Oleh itu, item ini sesuai dan boleh diterima dalam kajian ini.

\section{Item Bidang Perkaitan Mengikut Herarki TPM}

Item bidang Perkaitan yang dibentuk dalam kajian ini adalah selari dengan Huraian Sukatan Pelajaran Matematik Tingkatan 2 dan 3 (Kementerian Pelajaran Malaysia, 2004) serta menggunakan buku teks matematik Tingkatan 2 (Koo, Chong, Lam, Heng \& Rahimah, 2012) dan buku teks matematik Tingkatan 3 (Lim, Koo, Chong \& Samadi, 2012). Berikut merupakan proses kogntif murid dalam menyelesaikan masalah matematik berdasarkan skrip jawapan ujian bertulis, analisis kandungan temu bual serta rakaman audio.

a) Soalan tahap hierarki 1:

Tuliskan rumus bagi $\mathrm{K}$ bersamaan dengan separuh daripada hasil tambah $\mathrm{M}$ dan N.

\begin{tabular}{|c|c|c|c|}
\hline \multirow[b]{2}{*}{$\begin{array}{l}\text { Sumber Luaran } \\
\text { (SL) }\end{array}$} & \multirow{2}{*}{$\begin{array}{c}\text { Memori Jangka } \\
\text { Pendek/Memori Kerja } \\
\text { (MD/MK) }\end{array}$} & \multicolumn{2}{|c|}{$\begin{array}{l}\text { Memori Jangka Panjang } \\
\text { (MP) }\end{array}$} \\
\hline & & $\begin{array}{l}\text { Maklumat } \\
\text { Jenis Semasa }\end{array}$ & $\begin{array}{l}\text { Maklumat } \\
\text { Jenis } \\
\text { Berkait }\end{array}$ \\
\hline $\begin{array}{c}\mathbf{1}) \\
\text { Separuh daripada }\end{array}$ & $\frac{1}{2}$ kali & & \\
\hline $\begin{array}{c}\text { (2) } \\
\text { Hasil tambah M dan N }\end{array}$ & $\left(\mathbf{2}^{\prime}\right)$ & & \\
\hline Rumus & (3') & & \\
\hline $\begin{array}{l}\text { Penyelesaian: } \\
\text { Rumus } \\
\mathrm{K}=\frac{1}{2}(M+N)\end{array}$ & (4) & & \\
\hline
\end{tabular}

Rajah 3 Laluan Pemprosesan Maklumat Mengikut Tahap Hierarki 1

b) Soalan tahap hierarki 2:

Aminah telah membeli sehelai seluar dan dua helai T-shirt di kedai pakaian dan membayar sebanyak RM 108. Harga sehelai seluar didapati RM 10 kurang daripada harga sehelai T-shirt. Cari harga sehelai T-shirt itu. 


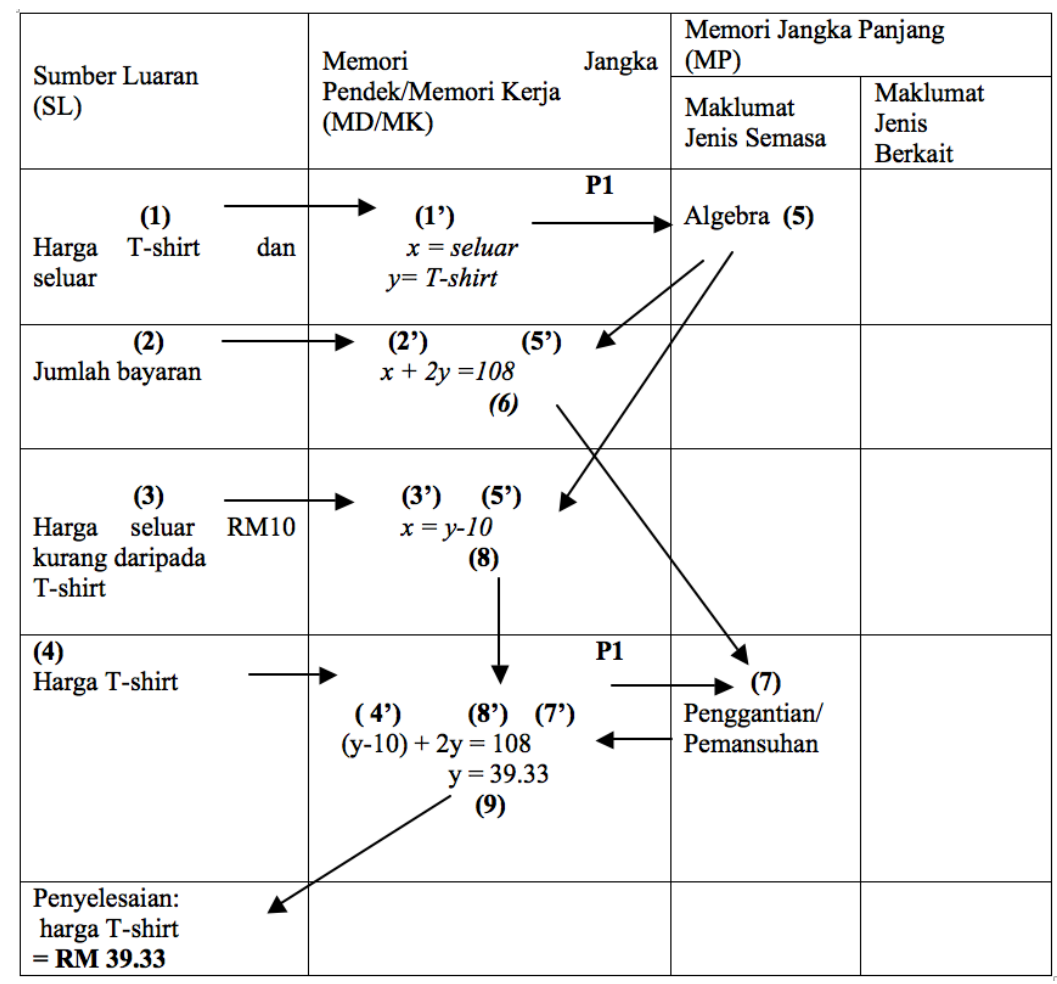

Rajah 4 Laluan Pemprosesan Maklumat Mengikut Tahap Hierarki 2

c) Soalan tahap hierarki 3:

Sebuah papan yang berbentuk segi empat tepat mempunyai lebar (a-3b) $\mathrm{cm}$. Manakala panjangnya adalah dua kali daripada lebar papan ini. Carikan perimeter bagi papan ini dalam sebutan a dan $b$ ? 
PEMBINAAN ITEM DALAM BIDANG PERKAITAN BAGI MATA PELAJARAN MATEMATIK TNGKATAN EMPAT BERDASARKAN MODEL TAKSONOMI PEMPROSESAN MAKLUMAT

\begin{tabular}{|c|c|c|c|}
\hline \multirow{2}{*}{$\begin{array}{l}\text { Sumber Luaran } \\
\text { (SL) }\end{array}$} & \multirow{2}{*}{$\begin{array}{l}\text { Memori Jangka Pendek/Memori } \\
\text { Kerja } \\
\text { (MD/MK) }\end{array}$} & \multicolumn{2}{|c|}{$\begin{array}{l}\text { Memori Jangka Panjang } \\
\text { (MP) }\end{array}$} \\
\hline & & $\begin{array}{l}\text { Maklumat Jenis } \\
\text { Semasa }\end{array}$ & $\begin{array}{l}\text { Maklumat Jenis } \\
\text { Berkait }\end{array}$ \\
\hline Lebar papan & $\rightarrow\left(\mathbf{1}^{\prime}\right) \quad$ Lebar $=a-3 b$ & & \\
\hline $\begin{array}{r}\text { (2) } \\
\text { Panjang papan }\end{array}$ & $\begin{aligned} & \mathbf{P 1} \\
& \overrightarrow{P a n j a n g}^{\left(\mathbf{2}^{\prime}\right)}\left.\mathbf{( 3}^{\prime}\right) \\
& 2(a-3 b) \\
&= 2 a-6 b \\
& \text { (4) }\end{aligned}$ & $\begin{array}{l}\text { (3) } \\
\text { Aritmetik }\end{array}$ & \\
\hline $\begin{array}{c}\text { (3) } \\
\text { Perimeter papan }\end{array}$ & $\begin{aligned} \longrightarrow & \mathbf{P 1} \\
& \left(\mathbf{3}^{\prime}\right) \\
& (a-3 b)+(2 a-6 b)+ \\
& (a-3 b)+(2 a-6 b) \\
= & 6 a-18 b \quad(6)\end{aligned}$ & & $\begin{array}{l}\rightarrow \\
-\quad(5) \\
\text { Formula } \\
\text { Perimeter }\end{array}$ \\
\hline $\begin{array}{l}\text { Penyelesaian: } \\
\text { perimeter papan } \\
=6 a-18 \mathrm{~cm}\end{array}$ & & & \\
\hline
\end{tabular}

Rajah 5 Laluan Pemprosesan Maklumat Mengikut Tahap Hierarki 3

d) Soalan tahap hierarki 4:

Kereta Ali dan kereta Ming bertolak dari Kuala Lumpur ke Melaka pada pukul 11.00 a.m. Laju purata kereta masing-masing ialah $75 \mathrm{~km} / \mathrm{j}$ dan 60 $\mathrm{km} / \mathrm{j}$. Jika Ali tiba di Melaka pada pukul 1.00 p.m., pada pukul berapakah Ming akan tiba di Melaka?

\begin{tabular}{|c|c|c|c|}
\hline \multirow{2}{*}{$\begin{array}{l}\text { Sumber Luaran } \\
\text { (SL) }\end{array}$} & \multirow{2}{*}{$\begin{array}{l}\text { Memori Jangka Pendek/Memori } \\
\text { Kerja } \\
\text { (MD/MK) }\end{array}$} & \multicolumn{2}{|c|}{$\begin{array}{l}\text { Memori Jangka Panjang } \\
\text { (MP) }\end{array}$} \\
\hline & & $\begin{array}{l}\text { Maklumat Jenis } \\
\text { Semasa }\end{array}$ & $\begin{array}{l}\text { Maklumat } \\
\text { Jenis } \\
\text { Berkait }\end{array}$ \\
\hline $\begin{array}{l}\text { (1) } \\
\text { Laju purata kereta Ali }\end{array}$ & $\vec{A}=75 \mathrm{~km} / \mathrm{j}$ & & \\
\hline \multirow[t]{2}{*}{$\begin{array}{l}\text { (2) } \\
\text { Bertolak 11.00a.m } \\
\text { Sampai } 1.00 \text { p.m. }\end{array}$} & $\begin{array}{l}\left.\mathbf{( 2}^{\prime}\right) \quad\left(\mathbf{5}^{\prime}\right) \\
1300-1100=2 \mathrm{jam} \\
(\mathbf{6})\end{array}$ & $\overrightarrow{A r i t m e t i k}^{(5)}$ & \\
\hline & $\begin{array}{l}1 \mathrm{jam}=75 \mathrm{~km} \\
2 \mathrm{jam}=150 \mathrm{~km}(\mathbf{8})\end{array}$ & $\begin{array}{c}\text { Kadaran/ } \\
\text { Unitari }\end{array}$ & \\
\hline \multirow[t]{2}{*}{$\begin{array}{l}\text { (3) } \\
\text { Laju purata kereta Ming }\end{array}$} & $\stackrel{\left(3^{\prime}\right)}{\longrightarrow} \mathrm{M}^{=} 60 \mathrm{~km} / \mathrm{j}$ & & \\
\hline & 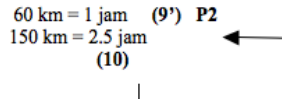 & $\begin{array}{l}\text { Kadaran/ } \\
\text { Unitari }\end{array}$ & \\
\hline $\begin{array}{l}\text { (4) } \\
\text { Waktu Ming tiba }\end{array}$ & 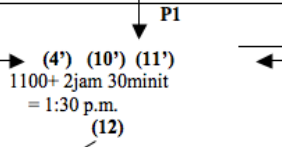 & $\rightarrow_{\text {Aritmetik }}^{(11)}$ & \\
\hline $\begin{array}{l}\text { Penyelesaian: } \\
\text { Ming tiba pada puku } \\
\text { 1:30p.m. }\end{array}$ & & & \\
\hline
\end{tabular}

Rajah 6 Laluan Pemprosesan Maklumat Mengikut Tahap Hierarki 4 
e) Soalan tahap hierarki 5:

Sebuah tangki air yang mempunyai tapak berbentuk segi empat sama telah bocor dan dan menghilangkan air sebanyak $3 \mathrm{~m}^{3}$ dalam masa 2 jam. Jika sisi tapak tangki ialah $2.5 \mathrm{~m}$, cari ketinggian tangki air yang telah disusut selepas 3 jam.

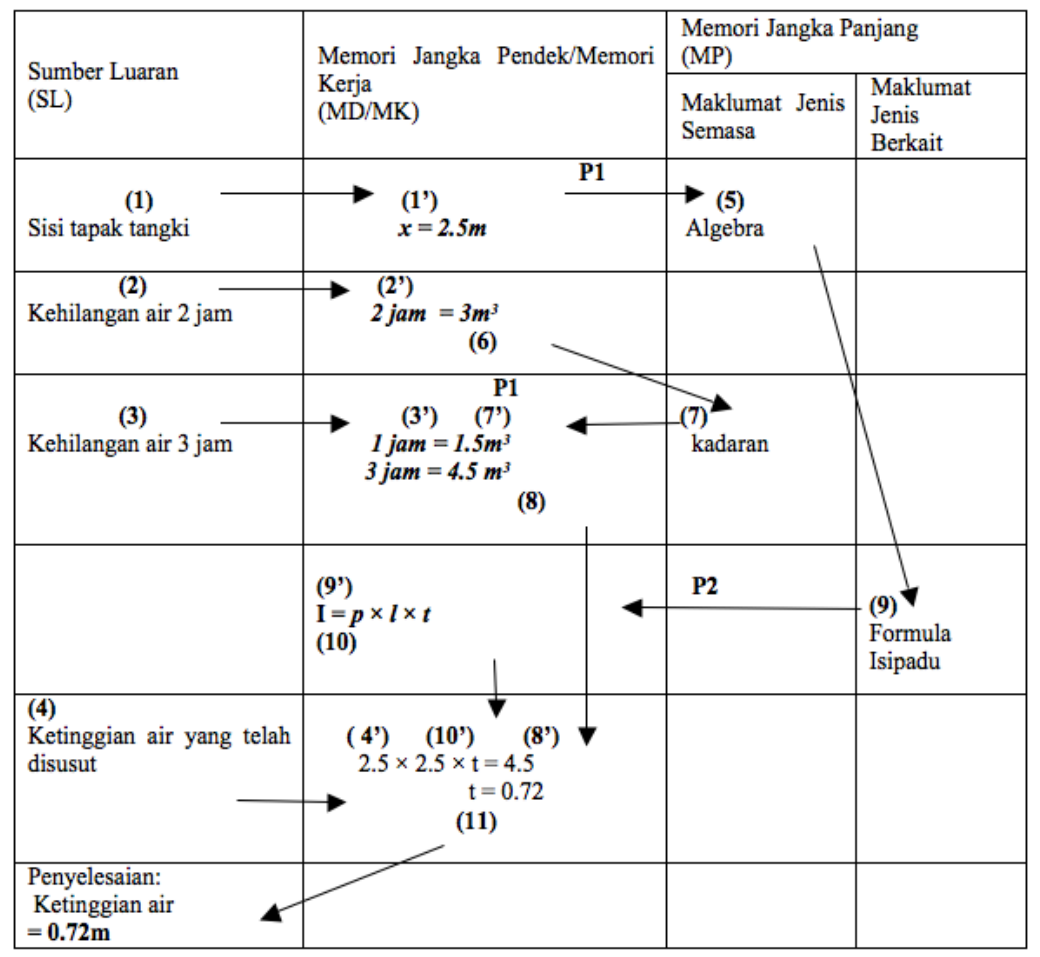

Rajah 7 Laluan Pemprosesan Maklumat Mengikut Tahap Hierarki 5

\section{PERBINCANGAN}

Bahagian ini membincangkan dimensi pengetahuan dan proses kognitif item yang dibina mengikut Krathwohl (2002).

\section{a) Item Tahap Hierarki 1}

Untuk menyelesaikan soalan ini, murid perlu mengambil tahu maklumat dari SL sahaja. Murid cuba memahami dan mengingati pengetahuan yang dipelajari serta menghubung kait antara unsur-unsur asas untuk menjadi struktur yang lebih besar atau yang boleh berfungsi. Unsur-unsur asas soalan ini ialah separuh, hasil tambah dan membina rumus (struktur). Oleh itu, soalan ini sudah cukup mencapai aras pengetahuan konseptual (Krathwohl, 2002).

Dari segi proses kognitif, soalan ini masih dalam proses mengingat dan memahami, iaitu soalan beraras rendah mengikut Anderson dan Krathwohl (2001). Oleh itu, tiada kemahiran berfikir diperlukan untuk menyelesaikan soalan ini. Ini terbukti dalam dapatan kaijan bahawa semua murid berpencapaian cemerlang, sederhana dan seorang murid berpencapaian lemah berjaya menyelesaikan soalan ini. 


\section{b) Item Tahap Hierarki 2}

Murid perlu mengambil tahu maklumat dari SL dan MP untuk menyelesaikan soalan tahap hierarki 2. Murid perlu memahami dan mengingati pengetahuan yang dipelajari serta mengetahui bagaimana untuk menggunakan kemahiran matematik untuk menyelesaikannya. Kemahiran matematik yang digunakan dalam soalan ini ialah algebra dan penggantian/ pemansuhan dan dikenali sebagai maklumat jenis semasa. Oleh itu, soalan ini telah mencapai aras pengetahuan prosedural (Purwoko, 2016).

Dari segi dimensi proses kognitif, soalan ini melibatkan proses mengingat, memahami, menerap, menganalisis dan menilai (Krathwohl, 2002). Proses mencapai aras menerapkan apabila wujudnya P1 murid. Maklumat yang dicungkil oleh P1 dan MK digunakan untuk proses menganalisis dan menilai. Tahap kemahiran berfikir soalan ini adalah lebih tinggi dari tahap hierarki 1 (Fong, 1994). Ini terbukti dalam dapatan kajian bahawa hanya murid berpencapaian cemerlang dan sederhana sahaja dapat menyelesaikan soalan ini dengan betul.

\section{c) Item Tahap Hierarki 3}

Untuk menyelesaikan soalan tahap hierarki 3, murid perlu mengambil tahu maklumat dari SL dan MP untuk menyelesaikan soalan. Murid perlu memahami dan mengingat pengetahuan yang dipelajari serta mengetahui bagaimana untuk menggunakan kemahiran matematik untuk menyelesaikannya. Kemahiran matematik yang digunakan dalam soalan ini ialah algebra dan formula perimeter. Algebra dikenali sebagai maklumat jenis semasa dan formula perimeter dikenali sebagai maklumat jenis berkait. Oleh itu, soalan ini sudah cukup mencapai aras pengetahuan prosedural (Purwoko, 2016).

Dari segi dimensi proses kognitif, soalan ini melibatkan proses mengingat, memahami, menerap, menganalisis dan menilai (Krathwohl, 2002). Proses mencapai aras menerapkan apabila wujudnya P1 murid dalam menyelesaikan masalah. Maklumat yang dicungkil oleh P1 dan MK digunakan untuk proses menganalisis dan menilai. Tahap kemahiran berfikir soalan ini adalah lebih tinggi dari tahap hierarki 2 (Fong, 1994). Ini terbukti dalam dapatan kajian bahawa semua murid berpencapaian cemerlang dan dua orang murid berpencapaian sederhana sahaja dapat menyelesaikan soalan ini dengan betul.

\section{d) Item Tahap Hierarki 4}

Untuk menyelesaikan soalan tahap hierarki 4, murid perlu mengambil tahu maklumat dari SL dan MP untuk menyelesaikan soalan. Murid perlu memahami dan mengingat pengetahuan yang dipelajari, mengetahui bagaimana untuk menggunakan kemahiran matematik serta mempunyai kesedaran dan pengetahuan kognisi sendiri untuk menyelesaikannya. Kemahiran matematik yang digunakan dalam soalan ini ialah aritmetik (maklumat jenis semasa) dan pengetahuan kognisi sendiri ialah kadaran/ unitari atau formula. Oleh itu, soalan ini sudah cukup mencapai aras pengetahuan metakognitif (Krathwohl, 2002).

Dari segi dimensi proses kognitif, soalan ini melibatkan proses mengingat, memahami, menerap, menganalisis dan menilai (Krathwohl, 2002). Proses mencapai aras menerapkan apabila wujudnya P1 dan sistem pengeluar sekunder (P2) murid. 
Maklumat yang dicungkil oleh P1, P2 dan MK digunakan untuk proses menganalisi dan menilai. Tahap kemahiran berfikir soalan ini adalah lebih kompleks dan sukar dari tahap hierarki 3 (Fong, 1994). Ini terbukti dalam dapatan kajian bahawa hanya murid berpencapaian cemerlang sahaja dapat menyelesaikan soalan ini dengan betul.

\section{e) Item Tahap Hierarki 5}

Seterusnya, untuk menyelesaikan soalan tahap hierarki 5, murid perlu mengambil tahu maklumat dari SL dan MP untuk menyelesaikan soalan. Murid perlu memahami dan mengingat pengetahuan yang dipelajari, mengetahui bagaimana untuk menggunakan kemahiran matematik serta mempunyai kesedaran dan pengetahuan kognisi sendiri untuk menyelesaikannya. Kemahiran matematik yang digunakan dalam soalan ini ialah algebra dan kadaran/ unitari (maklumat jenis semasa). Manakala pengetahuan kognisi sendiri ialah formula isipadu (maklumat jenis berkait). Oleh itu, soalan ini sudah cukup mencapai aras pengetahuan metakognitif (Krathwohl, 2002).

Dari segi dimensi proses kognitif, soalan ini melibatkan proses mengingat, memahami, menerap, menganalisis dan menilai (Krathwohl, 2002). Proses mencapai aras menerapkan apabila wujudnya P1 atau P2 murid. Maklumat yang dicungkil oleh P1, P2 dan MK digunakan untuk proses menganalisis dan menilai. Tahap kemahiran berfikir soalan ini adalah kompleks dan sukar (Fong, 1994). Ini terbukti dalam dapatan kajian bahawa hanya murid berpencapaian cemerlang sahaja dapat menyelesaikan soalan ini dengan betul.

\section{KESIMPULAN KAJIAN}

Kajian ini menunjukkan bahawa lima item bidang Perkaitan dapat dibina dengan kesahan yang tinggi dan kebolehpercayaan yang baik. Setiap soalan adalah dibina mengikut ciri-ciri TPM, iaitu mencungkil maklumat dari SL, MP dan MK. Manakala pengaktifan P1 dan P2 merupakan sistem yang dibangkitkan oleh murid semasa menyelesaikan masalah untuk membezakan tahap pemikiran murid serta menggambarkan proses kognitif murid. Untuk soalan tahap hierarki 1, maklumat dari SL adalah dihubung kait dengan kehendak jawapan secara langsung. Dengan itu, fakta dan kata kunci matematik perlu diketahui dan difahami dengan cukup untuk menyelesaikan masalah ini. Selain itu, murid juga harus berupaya untuk membuat perwakilan matematik seperti menukarkan ayat-ayat soalan menjadi persamaan atau ungkapan algebra, mencari hubung kait antara cebisan-cebisan maklumat serta menentukan operasi matematik yang bersesuaian semasa menyelesaikan masalah.

Pada tahap hierarki 2, penguasaan matematik murid dapat dilihat seperti mengendalikan persamaan algebra, penambahan, pendaraban, penggantian/ pemansuhan, kadaran dan lain-lain kemahiran matematik dalam bidang Perkaitan Tingkatan 2 dan 3 sahaja. Ini merupakan maklumat jenis semasa berdasarkan model TPM. Manakala tahap hierarki 3 memerlukan penguasaan matematik murid dalam bidang yang lain seperti bidang ruang dan bentuk yang dianggap sebagai maklumat jenis berkait. Oleh itu, pada tahap sebegini, murid perlu berupaya merangsang maklumat di MP dengan menggunakan maklumat di SL. Maklumat di MP kemudian dioperasi dengan sistematik dan teratur di medan operasi MK sehingga penyelesaian. Seterusnya, untuk menyelesaikan masalah tahap hierarki yang lebih tinggi iaitu tahap hierarki 4 dan 5. Pada tahap ini, murid perlu membangkitkan pengetahuan kognisi sendiri untuk menyelesaikan masalah. Murid perlu ada kesedaran bahawa maklumat 
yang tersirat sama ada di SL, MK atau yang dicungkil oleh P1 untuk mengaktifkan P2 mereka.

Dapatan kajian ini boleh dijadikan satu rujukan tambahan kepada pendidik yang berminat dalam proses kognitif murid. Ini kerana langkah-langkah penyelesaian masalah berdasarkan model TPM (Fong, 1994) boleh digambarkan dalam laluan pemprosesan maklumat pada setiap tahap hierarki dengan lebih jelas dan terperinci.

\section{RUJUKAN}

Anderson, L. W. \& Krathwohl, D. R. (2001). A taxonomy for learning, teaching and assessing. New York: Addison Wesley Longman.

Bloom , B. S. (1956). Taxonomy of educational objectives: the classification of educational goals. New York: Longmans.

Driscoll, M. P. (2005). Psychology of learning for instruction. Toronto, ON: Pearson.

Egodawatte, G. (2001). Secondary school Students' misconceptions in Algebra. Doctor of Philosophy, University of Toronto.

Faridah Hanim Omar (2003). Pelaksanaan pembelajaran koperatif dalam mata pelajaran Matematik di sebuah sekolah menengah: Satu Kajian Kes. Sarjana Pendidikan yang tidak diterbitkan. Bangi, Malaysia: Universiti Kebangsaan Malaysia.

Faridah Salleh \& Effandi Zakaria. (2009). Non-routine problem solving and attitudes towards problem-solving among high achievers, The International Journal of Learning, 16(5), 549-559.

Fong, H. K. (1994). Information Processing Taxonomy (IPT): An alternative technique for assessing mathematical problem-solving. Singapore Journal of Education, 14(1), 31-45.

Fong, H. K. (1997). Children's productive thinking in solving a ratio and proportion problem .The Mathematics Educator, 2(2), 128-137.

Johanning, D. I. (2004). Supporting the development of algebraic thinking in middle school: A closer look at students' informal strategies. Journal of Mathematical Behavior, 23(4), 371-388.

Kaur, B. (2008). Teaching and learning of mathematics- What really matters to teachers and students? The International Journal on Mathematics Education, 40(6), 951-962.

Kementerian Pelajaran Malaysia. (2004). Integrated curriculum for secondary schools: Syllabus Mathematics. Putrajaya, Malaysia: Kementerian Pelajaran Malaysia.

Kementerian Pendidikan Malaysia. (2013). Pelan pembangunan Malaysia 20132025. Putrajaya, Malaysia: Kementerian Pendidikan Malaysia.

Kementerian Pendidikan Malaysia. (2015). Kurikulum Standard Sekolah Menengah Matematik Dokumen Standard Kurikulum dan Pentaksiran Tingkatan 1. Putrajaya, Malaysia: Kementerian Pendidikan Malaysia.

Kilpatrick, J. \& Swafford, J. (2002). Helping children learn mathematics. Washington, DC: National Academy Press.

Koo S. H., Chong G. C., Lam Y. S., Heng S. K. \& Rahimah Jantan. (2012). Kurikulum Bersepadu Sekolah Menengah: Matematik Tingkatan 2. Selangor Darul Ehsan: Pekan Ilmu Publication Sdn. Bhd.

Krathwohl, D. R. (2002). A revision of Bloom's Taxonomy: An overview. College of Education: Theory into Practice, 41(4), 212-218. 
Landis, J. \& Kosh, G. G. (1977). The measurement of observer agreement for categorical data. Biometrics, 33: 159-174.

Lester, F.K. (2013). Thoughts about research on mathematical problem solving instruction. Dlm. L. Sontos-Trigo \& L. Moreno-Armella (pnyt.), International Perspectiveson Problem Solving Research in Mathematics Education, a special issue. The mathematics Enthusiast, 10: 245-278.

Lim S. H., Koo, S. H., Chong, Chong, G. H. \& Samadi Hashim. (2012). Kurikulum Bersepadu Sekolah Menengah: Matematik Tingkatan 3. Kuala Lumpur: Darul Fikir.

Lutz, S. \& Huitt, W. (2003). Information processing and memory: Theory and applications. Educational Psychology Interactive. Valdosta, GA: Valdosta State University

Macintosh, H. G. \& Morrisson, R. B. (1969). Objective testing. London: University of London Press Ltd.

Mullis, I. V. S., Martin, M. O., Minnich, C. A., Stanco, G. M., Arora, A., Centurino, V. A. S. \& Castle, C. E. (Eds). (2012). TIMSS 2011 encyclopedia: Education policy and curriculum in mathematics and science (Vol. 1-2). Chestnut Hill, MA: TIMSS \& PIRLS International Study Center, Boston College.

National Council of Teacher of Mathematics (NCTM). (2014). Principles to Actions Ensuring Mathematical Success for All. Reston, VA: NCTM.

Nik Aziz Nik Pa \& Noraini Idris. (2008). Perjuangan memperkasakan pendidikan di Malaysia: Pengalaman 50 tahun merdeka. Kuala Lumpur: Utusan Publication \& Distributors Sdn Bhd.

Nor'ain Mohd Tajudin \& Chinnappan, M. (2016). The link between higher order thinking skills, representation and concepts in enhancing TIMSS tasks. International Journal of Instruction, 9(2), 199-214.

Pusat Perkembangan Kurikulum. (2012). Kurikulum standard sekolah menengah (KSSM). Kuala Lumpur: Kementerian Pelajaran Malaysia

Purwoko. (2016). Proses kognitif murid sekolah menengah pertama dalam penyelesaian masalah algebra berasaskan model taksonomi pemprosesan maklumat. Tesis Doktor Falsafah yang tidak diterbitkan. Tanjung Malim, Malaysia: Universiti Pendidikan Sultan Idris.

Roslina Radzali. (2007). Kepercayaan matematik, metakognisi, perwakilan masalah dan penyelesaian masalah matematik dalam kalangan pelajar. Tesis Doktor Falsafah yang tidak diterbitkan. Bangi, Malaysia: Universiti Kebangsaan Malaysia.

Salmah Fattah. (2003). Penggunaan konsep Taksonomi Bloom pada bank soalan atas talian. Tesis Sarjana Teknologi Maklumat yang tidak diterbitkan. Bangi, Malaysia: Universiti Kebangsaan Malaysia.

Schoenfeld, A. H. (2013). Reflections on problem solving theory and practice. Dalam L. Santos-Trigo \& L. Moreno-Armella (pyt), International Perspectives on Problem Solving Research in Mathematics Education, a special issue. The Mathematics Enthusiast, 10(1\&2), 9-34.

Selvamarry, U. (2013). Analisis jenis kesilapan melalui kaedah Newman dan strategi penyelesaian masalah berayat matematik dalam kalangan pelajar tingkatan dua. Tesis Sarjana yang tidak diterbitkan. Tanjung Malim, Malaysia: Universiti Pendidikan Sultan Idris. 
Siti Hadijah Harun. (2010). Strategi penyelesaian masalah fizik bukan rutin jenis terbuka dalam kalangan murid sekolah. Tesis sarjana yang tidak diterbitkan. Bangi, Malaysia: Universiti Kebangsaan Malaysia.

Tengku Zawawi Tengku Zainal. (2005). Pengetahuan pedagogi isi kandungan bagi tajuk 'Pecahan' di kalangan guru sekolah rendah. Tesis Doktor Falsafah yang tidak diterbitkan. Bangi, Malaysia: Universiti Kebangsaan Malaysia.

Wiersman, W. (2000). Research method in education: An introduction. Needham Heights, NY: Allyn \& Bacon.

Zabani Darus. (2012). Status pencapaian Malaysia dalam TIMSS dan PISA: Satu Refleksi. KPM. https://www.scribd.com/document/122745513/SKOR-TIMMS.

Zarimah Zainal. (2010). Metakognisi dalam proses penyelesaian masalah matematik bukan rutin dalam kalangan pelajar tingkatan empat: Satu Kajian Kes. Tesis Sarjana yang tidak diterbitkan. Tanjung Malim, Malaysia: Universiti Pendidikan Sultan Idris.

Zatur Junaida Bandong. (2004). Kesan penggunaan latihan metakognitif dalam menyelesaikan masalah pembelajaran matematik di sekolah rendah: Satu Kajian Kes. Tesis Sarjana Muda yang tidak diterbitkan. Sarawak, Malaysia: Universiti Malaysia Sarawak. 